\title{
EDTV における動き適応垂直時間補強信号の提案
}

\author{
正会員 吹 抜 敬 彦 ${ }^{\dagger}$, 正会員 鈴 木 教 洋 ${ }^{\dagger}$, 正会員 影 山昌 広 ${ }^{\dagger}$
}

\section{Motion-Adaptive Vertical-Temporal Helper Signal for EDTV}

\author{
Takahiko Fukinuki $^{\dagger}$, Norihiro Suzuki $^{\dagger}$ and Masahiro Kageyama ${ }^{\dagger}$
}

\begin{abstract}
In EDTV-II, a letterbox format is used for wide-aspect ratio. VT (Vertical-Temporal) and VH (Vertical High) helper signals are transmitted in the top and bottom black bars of a $4: 3$ transmitted signal. This paper proposes a motion-adaptive LD (Line Difference)/FD (Frame Difference) hybrid signal for the VT. In the motion adaptive hybrid method, the FD is used in stationary areas and the LD in moving areas. And because the signal with less energy is motion-adaptively selected, the hybrid signal is less visible on current receivers. Transmission noise in EDTV receivers can be reduced by coring and non-linear amplitude companding techniques. The proposed method can be implemented by adding only a few circuits to IDTV receivers (Clear-Vision receivers). Simulation results have clarified that the proposed signal is less annoying than the LD and FD signals.
\end{abstract}

\section{1. まえ がき}

ワイド化, 高画質化, 高音質化を目指した第 2 世代 EDTVの標準化作業が進められている.ワイド化は レターボックス方式にて行い, 高画質化については, 水平高域 $(\mathrm{HH})$, 垂直高域 $(\mathrm{VH})$, 垂直時間高域 (VT)の補強が行われる. HH 信号は画面内に多重さ れ，VH，VT 信号は上下無画部に多重される。本論 文においては, これらの補強信号のうちVT信号に ついて方式提案を行う.

VT 信号は, 受像機側での [飛越し-順次] 走査変換 のための補強信号であり ${ }^{1)}$, 飛越し走査における [垂 直-時間]周波数領域での縮退による誤動作(画質劣化) を解消するのが主目的である。

ここに縮退とは, 静止垂直高域成分と動垂直低域成
分が周波数領域で同一になってしまうことをいう。こ の意味では, VT 信号は, 動領域における垂直高域成 分を補強する信号というよりは, 縮退解除 (de-degeneration) 信号と考える方が悞解を招かない.

VT 信号としては, 同一フレーム (順次)内の走査線 間差分 (LD：Line Difference) 信号 ${ }^{122)}$ と，フレーム間 差分(FD：Frame Difference) 信号 ${ }^{3)}$ の 2 つが主に検 討されてきた。

一般にVT 信号は, 現行受像機での無画部妨害が 目立たず, EDTV受像機においてノイズによる画質 劣化が少ないことが必要である.

筆者らは妨害の少ないVT 信号の提案を行う。ま た, 提案手法におけるノイズ劣化軽減手法についても 検討を加える。

本論文では，まずVT 信号の概略を述べる．次に，

\section{キーワード : EDTV, 垂直時間補強信号}

1993 年 3 月 19 日, テレビジョン学会放送方式研究会で発表

1993 年 11 月 22 日受付, 1994 年 4 月 19 日最終受付

$\dagger$ 株式会社日立製作所 中央研究所（广 185 国分寺市東恋ヶ宔 1-280, TEL 0423-23-1111）

$\dagger$ Central Research Laboratory, Hitachi, Ltd. (1-280, Higashi-Koigakubo, Kokubunji-shi, Tokyo 185, Japan) 


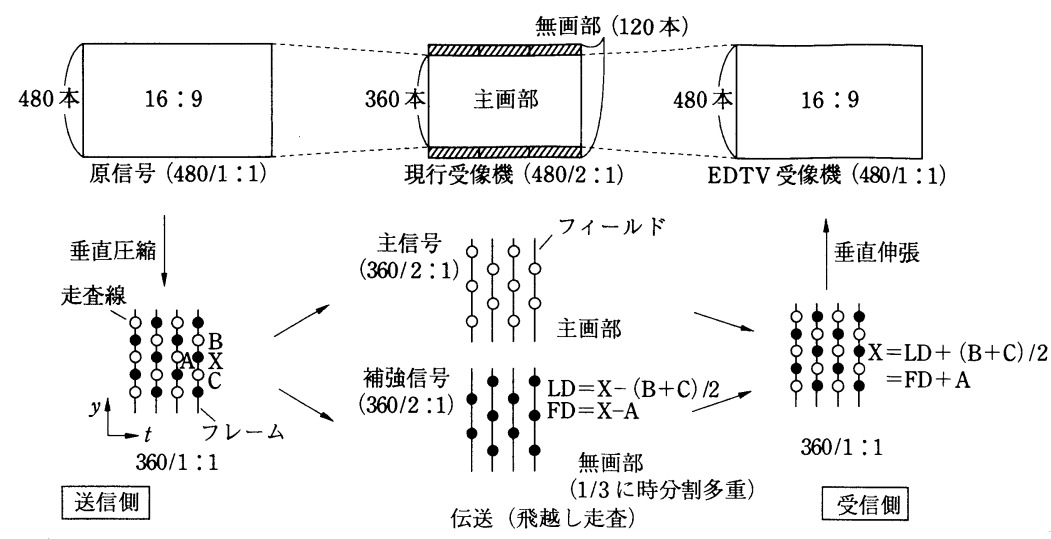

表 1 VT 信号の分類 Classification of VT signals.

\begin{tabular}{c|l}
\hline \hline 大分類 & \multicolumn{1}{c}{ 小分類 } \\
\hline \multirow{4}{*}{$\mathrm{LD}$ (広義) } & $\mathrm{LD}\left(\right.$ 狭義 $^{2)}$ \\
\cline { 2 - 2 } & $\begin{array}{l}\mathrm{SSKF} \text { (Symmetric } \\
\text { Short Kernel Filter) }\end{array}$ \\
\hline \multirow{2}{*}{$\mathrm{FD}$} & 逐次 $\mathrm{FD}^{3)}$ \\
\cline { 2 - 2 } & フレーム完結 $\mathrm{FD}^{6)}$ \\
\hline \multirow{4}{*}{$\mathrm{LD} / \mathrm{FD}$} & 固定混合 $(3$ 章参照) \\
\cline { 2 - 2 } & $\begin{array}{l}\text { 動き適応混合 } \\
\text { (3 章参照) }\end{array}$ \\
\hline
\end{tabular}

図 1 VT 信号処理

VT signal processing.

LD, FD 信号の統一的表記を定義し, LD/FD 混合方 式を提案する. 提案手法の得失, 受像機のハードウェ ア構成について検討を加え，ノイズの影響についても 解析を行う。最後に, LD/FD 混合方式と他のVT 信 号との比較を行う。

\section{VT 信号の概略}

\section{$2.1 \mathrm{VT}$ 信号の目的と分類}

前述のように, VT 信号の目的は，受信側における 順次走查化において, 縮退による誤動作を解消するこ とにある。縮退があると，動領域が静止領域と誤判定 され，正しい順次走査化ができないからである．

図 1 にVT 信号処理の概略を示す。送信側で [順次 -飛越し]走査変換の際, 白丸 $(\bigcirc)$ で示す主信号と黒丸

（の）で示すVT 信号が作成される. 正しい順次走査 化のためには, 主信号とVT 信号は完全再構成の条 件を満足する必要がある4).

VT 信号は，フィールド内演算による信号(広義の $\mathrm{LD})$ ，フィールド間演算による信号 $(\mathrm{FD})$ および，本 論文で提案する両者の混合信号 $(\mathrm{LD} / \mathrm{FD})$ の 3 つに大 別できる.さらに各信号は表 1 のように分類できる.

広義の $\mathrm{LD}$ のうち, $\mathrm{LD}$ (狭義) 信号 ${ }^{2}$ は上下の走査 線平均との差分により得られる。 また, SSKF 方式 ${ }^{5)}$ では主信号とVT 信号の分離・合成に SSKF (Symmetric Short Kernel Filter)を用いる.

$\mathrm{FD}$ のうち, 逐次 FD 信号 ${ }^{3)}$ は前フレーム (順次) と の差分により得られる。また, フレーム完結 FD 信 号6) はフレーム(飛越し時) 単位の処理を行うため, 奇 数と偶数フィールドで処理が異なる．例えば，奇数フ ィールドでは後フレーム(順次)との差分によって得， 偶数フィールドでは前フレーム (順次) との差分によっ て得られる。フレーム完結 FD 信号をさらに変形した
方式7)も提案されている.

このうち代表的な手法である LD(狭義) と逐次 FD の信号処理を図 1 に示した。作成されたVT信号は 無画部にて伝送される。受像機側では，主画部信号と の演算により順次走査信号を再生する。VT 信号 (360 本/フレーム) は無画部の 120 本/フレームに多重され るため, 帯域を映像帯域 $4.2 \mathrm{MHz}$ の $1 / 3$ の $1.4 \mathrm{MHz}$ 以下に制限し，時分割多重により伝送する。受像機側 では時間伸張処理により再生する。

\subsection{VT 信号選定の考え方}

VT 信号は次の条件を満たす必要がある。

(i ) 現行受像機において無画部妨害が見えにくい こと.

（ii） EDTV 受像機において $S / N$ 劣化が少ないこと。 後者（ii）では, VT 信号時間伸張による視覚的 $S / N$ 劣化に配慮する必要がある。これは, 時間伸長により 低域にノイズが集中するためである ${ }^{8)} . S / N$ 向上のた めには増幅して伝送することが考えられるが，このよ うにすると現行受像機では妨害が目立つ。このため, 双方の条件はトレードオフの関係にある。この条件に ついて以下のように考光る。

（i ）電力の小さいVT 信号を選ぶ：信号自体の 電力を減らし，妨害を目立ちにくくしたい。な お，原信号に［垂直-時間］前置フィルタをかけ る ${ }^{9)} も 一$ 改善手法である.

(ii) 大振幅 VTは非線形振幅圧伸にて回避す る：非線形振幅圧伸では，映像帯域 $4.2 \mathrm{MHz}$ フィルタのために高調波が伝送できず，圧伸歪 みが生じる9 。広義の LD の場合には，静止画 時にも垂直高域を含む領域でフリッカを生じ る。一方，FD の場合には，動画領域のみ歪み が生じ視覚的な劣化は少ないため, 問題は少な 
ᄂ.

（iii）ノイズはコアリングにて改善する：VT 信号 が寄与しない時には，コアリング( 0 近傍の信 号レベルを０にする）により信号を止める。非 線形振幅圧伸と同様の理由で，広義の LD の場 合にはフリッカが生じるため問題がある。一 方, FDの場合, 静止領域では歪みが存在しな いため，LDに比べ問題が少ない.

以上の観点から, 各種 VT 信号の比較 (後述の LD/ $\mathrm{FD}$ を含む)を表 2 に示す. 広義の LD と FDを比較 すると, 非線形振幅圧伸やコアリングの可能性などか らは, FD 信号の方が有利と思われる。

\section{3. $\mathrm{LD} / \mathrm{FD}$ 混合方式}

無画部妨害をさらに低減するには，VT 信号自体の 電力を小さくすることが望ましい.この可能性がある
VT 信号を提案する.

まず，LD，FD信号を含めてVT 信号を統一的に 表記する。以下では, LD は LD(狭義)を表し, FD は逐次 FDを表すものとする. 走査線の位置と記号を 図 2 に示す。ここで伝送されない走査線 X の位置の VT 信号を考える。まず，LD，FD信号は下式により 生成される.

$$
\begin{aligned}
& \mathrm{LD}=\mathrm{X}-(\mathrm{B}+\mathrm{C}) / 2 \\
& \mathrm{FD}=\mathrm{X}-\mathrm{A}
\end{aligned}
$$

ここで $\mathrm{LD}, \mathrm{FD}$ 信号の双方を, パラメータ $k$ を使っ て統一的に表記する.

$$
\begin{aligned}
\mathrm{VT} & =(1-k)+\mathrm{FD}+k \cdot \mathrm{LD} \\
& =(1-k) \cdot(\mathrm{X}-\mathrm{A})+k \cdot[\mathrm{X}-(\mathrm{B}+\mathrm{C}) / 2] \\
& =\mathrm{X}-[(1-k) \cdot \mathrm{A}+k \cdot(B+C) / 2]
\end{aligned}
$$

\begin{tabular}{|c|c|c|c|c|c|c|}
\hline & \multicolumn{2}{|c|}{$\mathrm{LD}($ 広義) *1 } & \multicolumn{2}{|c|}{ LD/FD 混合*1 } & \multicolumn{2}{|c|}{$\mathrm{FD}^{* 1}$} \\
\hline & LD (狭義) & $\operatorname{SSKF}$ (狭義) & 固定 & 動き適応 & 逐次 & フレーム完結 \\
\hline フィールド完結性 & \multicolumn{2}{|c|}{ ○あり } & \multicolumn{4}{|c|}{ なし } \\
\hline $\begin{array}{l}\mathrm{ED} \text { 受像機 } 360 \mathrm{lph} \text { 再生, } \\
\& \text {, 現行受像機フリッカ } \\
\text { 軽減 }\end{array}$ & 不可 & ○可 & \multicolumn{4}{|c|}{ 不可 } \\
\hline $\begin{array}{l}\text { 現行受像機における } \\
\text { 無画部の妨害 }\end{array}$ & \begin{tabular}{l|} 
垂直高域部に発 \\
生. 静止領域に \\
も発生するため \\
妨害感が強い.
\end{tabular} & 同左 & $\begin{array}{l}\text { 動領域, 静止領 } \\
\text { 域とも, LD(広 } \\
\text { 義)とFDの妨 } \\
\text { 害を半減する. }\end{array}$ & \begin{tabular}{|c|} 
○動画領域のみ発 \\
生し, 妨害はFD \\
より軽減される.| \\
○非線形圧伸, \\
妨害軽隇のた \\
必要は小.
\end{tabular} & \multicolumn{2}{|c|}{$\begin{array}{l}\text { 動画領域のみ発生. LD(広義) } \\
\text { より目立ちにくい. } \\
\text { コアリング(下記)を考慮すれば, } \\
\text { めに伝送 VT 信号を減衰させる }\end{array}$} \\
\hline $\begin{array}{l}\text { 非線形圧伸 } \\
\text { (現行受像機無画部妨害 } \\
\text { 対策) }\end{array}$ & \multicolumn{3}{|c|}{$\begin{array}{l}\text { 視覚的劣化が大きい. } \\
\text { (ED 受像機復調主画面の静止領域で, 圧伸歪) } \\
\text { みによりフリッカが発生する. }\end{array}$} & \multicolumn{3}{|c|}{ 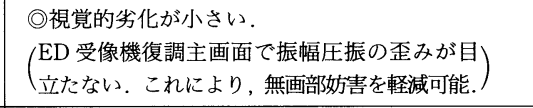 } \\
\hline $\begin{array}{l}\text { ノイズ対策 } \\
\text { (ED受像機復調主画面) }\end{array}$ & \multicolumn{3}{|c|}{$\begin{array}{l}\text { コアリングは, } \\
\text { 静止領域にてフリッカ発生. } \\
\text { |受像側フィル夕| } \\
\text { によりノイズ軽 } \\
\text { 減可 }\end{array}$} & \multicolumn{3}{|c|}{$\begin{array}{l}\text { (○コアリング適用により, } \\
\text { 静止領域のノイズ低減可能. }\end{array}$} \\
\hline EDTV-I回路との整合性 & \multicolumn{3}{|c|}{ 新たな付加回路が必要. } & $\begin{array}{c}\text { ○順次走查化回路 } \\
\text { の流用可. } \\
\text { (動き検出問題小) }\end{array}$ & \multicolumn{2}{|c|}{ 新たな付加回路が必要. } \\
\hline その他 & $\begin{array}{l}\text { 信号処理が最も } \\
\text { 単純. }\end{array}$ & & $\begin{array}{l}\mathrm{LD} \text { (狭義) とほほ } \\
\text { 同様に単純. }\end{array}$ & \begin{tabular}{l|l} 
動き係数雑音に \\
よる雑音の相加 \\
分は小. ${ }^{* 3}$
\end{tabular} & $\begin{array}{l}\mathrm{LD} \text { (狭義) と同 } \\
\text { 様に単純. }\end{array}$ & $\begin{array}{l}\times \text { ×フールド遅延. } \\
\times \text { 第 } 1 / \text { 第 } 2 \text { フ } \\
\text { ールドでの処理 } \\
\text { が異なる. }\end{array}$ \\
\hline
\end{tabular}

代入すればわかるように， $k=0$ の時は FDを表し， $k$ $=1$ の時は LDを表す.

表 2 各種 VT 信号の比較表

Features of VT signals.

* 1: $\mathrm{VT}=(1-k) \mathrm{FD}+k \mathrm{LD}$

$=(1-k)(\mathrm{X}-\mathrm{A})+k[x-(\mathrm{B}+\mathrm{C}) / 2]$

$=\mathrm{X}-[(1-k) \mathrm{A}+k(\mathrm{~B}+\mathrm{C}) / 2]$

ここに, A: 前フレーム画素, B,C: 上下ライン画素.

(LD: $k=1$, 逐次 FD: $k=0$, 固定: $k=1 / 2$ 等,

動き適応: $k$ =動き係数)
*2: 送受とも飛越し走查より動き検出するので, 送受間の不整合 はなく，他の動き適応処理に見られるような問題は一切なし. $30 \mathrm{~Hz}$ 運動は静止とみなせばよいので, 順次走查化の際のよ うな縮退の対策は考えなくてよい.

* 3: 復調の際, VT の雑音のほか, 雑音による動き係数 $k$ の変動 による雑音が相加される.ただし， A が B と C の平均值のと き原理的に相加分 $=0$ であるなど, 相加分は小さい. 
ここで $k$ を 0,1 以外に一般的に拡張することによ り，新たな VT 信号を生成することができる， $k$ を固 定係数にする場合と可変係数にする場合の 2 つの方式 を提案する.

(i ) $\mathrm{LD} / \mathrm{FD}$ 固定混合方式： $k$ を固定係数にする. 例えば $k=1 / 2$ の場合は, 代入すると下式を得 る。

$$
\mathrm{VT}=\mathrm{X}-[\mathrm{A}+(\mathrm{B}+\mathrm{C}) / 2] / 2
$$

（ii）動き適応 $\mathrm{LD} / \mathrm{FD}$ 混合方式： $k$ を可変係数と する．本方式では $k$ として動き係数を採用す る.動き係数 $k$ は, 例えば, 送受ともに, フレ 一ム間差, $\mathrm{B}-\mathrm{B}^{*}$ と $\mathrm{C}-\mathrm{C}^{*}$ の絶対值和を $\mathrm{pp}$ (peak-to-peak) 值で正規化したものを用いる. ただし, 広範な隣接画素にて平滑化を行っても よい.

ここで重要なことは, 送受に同じ信号が存在するこ とである。このため, 雑音の影響を除くと $k$ の誤判 定(不整合)がない.すなわち，「IDTVにあった縮退 による動静誤判定」を避けることが本質的に可能であ る。

\section{4. $\mathrm{LD} / \mathrm{FD}$ 固定混合方式}

本方式 [垂直-時間] 周波数スペクトルは，(3)式よ り概念的に図 3 に示す通りになる。参考のため $\mathrm{FD}$; LD の場合も示した，本方式の特徵を以下に列挙す る.すなわち以下のように, $\mathrm{LD}, \mathrm{FD}$ 信号と比べて 中間的な性質を持つが, 無画部妨害の点では優位であ るといえる．

(i ) 無画部妨害：LD 信号では垂直高域部で目立 ち, FD 信号では動画部で目立つが, 本方式で はそれぞれの妨害の最悪値を半減する. 図 3 (c)から, 最も成分の少ない領域を通過域とし ていることがわかる。これより，LD, FD 信 号より妨害が目立たないことが予想される。

（ii）雑音の影響：非線形振幅圧伸，コアリングを
用いると，静止領域において歪みがフリッカと なるため, 上記手段の完全な適用は困難であ る.これは通常の LD 方式の特徵が半分現れる からである。

（iii）信号処理：図 2 よりわかるように, LD, FD 信号と同等の処理となる.

\section{5. 動き適応 LD/FD 混合方式}

\section{1 特徵の概略}

動き適応 LD/FD 混合方式では, 静止領域では FD が選択され, 動画領域では LD が選択される。この結 果, 以下のような特徵がある。なお下記 (i ) (ii)か ら, 補強信号の振幅を減衰することなく無画部に信号 を多重化できるので，等価的に補強信号に印加される 雑音は小さくなる．また次節以下で，(iii) 動き適応処 理とこれに関連する受像機側の構成を補足説明する。

（i） 無画部妨害：静動に応じ成分の小さいVT 信号が選択されるので, 現行受像機での妨害も 小さい.

（ii） 雑音の影響：静止領域では FD が選択される ため, 圧伸歪みの影響が少なく、コアリングが 可能であるなど, FDの利点はそのまま有して いる.

（iii）動き適応処理：IDTV における動き適応順次 走查化と異なり, 本方式の動き適応処理には無 理がない(5.3 節で述べる). また, 動き適応処 理したことによる $S / N$ 劣化の増加分はほとん どない（ 6 章で述べる）.

(iv） 信号処理：受像機は，IDTV 受像機に簡単な 回路の付加で実現できる (5.3 節で述べる).

（v） 運用上の問題：LD が飛越し走査状態におけ るフィールド単位に処理できるのに対して, 本 方式ではフィールドにまたがった処理となる。 ただし，放送局内では LD 信号を使用し，最終 送出段において LD/FD 混合信号を生成するこ

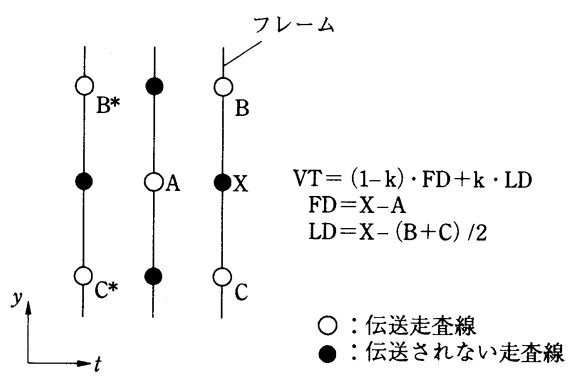

図 2 LD/FD 混合方式 LD/FD hybrid scheme.

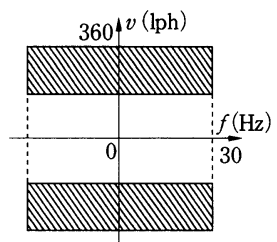

(a) LD

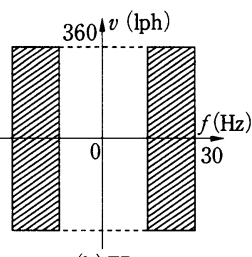

(b) FD

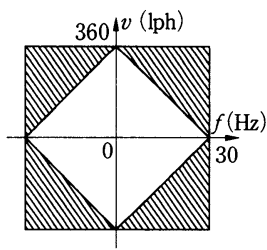

(c) LD/FD固定混合 $v$ : 垂直周波数 (lph : line per height) $f$ : 時間周波数

図 3 各 VT 信号の [垂直-時間］周波数スペクトル (概念的表示)

Vertical-temporal frequency spectra of VT signals. 
とは可能である.この時, 送出段では, LD 信 号と主画部信号より順次走査信号に変換した後 に LD/FD 混合信号を生成する。これにより局 内での編集などでの問題は解消する.

\section{2 動き適応処理について}

順次走查化に絡んだ動き適応処理は過去に苦労した 経緯があり, 是非とも避けたいという意見もあるよう である。しかし，本動き適応方式は従来のものと異な り, 以下のように無理がない手法である.

まず, 送受とも主画部の飛越し走査から動き検出す るので送受間の不整合はない.

また, かつての動き適応順次走査化では, 原理的に 区別できない [垂直-時間]での縮退が起き $(30 \mathrm{~Hz}$ の動 き), 動き検出に時空間積分などの対策を施す必要が あった ${ }^{10)}$. しかし, この混合方式では縮退の問題がな い. すなわち, $30 \mathrm{~Hz}$ の動きの場合には静止領域とし て FDが送られる.しかし, 受像機側においても静止 領域と判定され FD として再生される。

したがって，縮退による動きの誤検出があっても， 問題なく原順次信号が再生される。

さらに, 従来の適応処理では, 「動き」の測度とし て, 速さ (または速度) や振幅差など, いろいろと試 みられてきた。しかし本方式の場合, 無画部妨害を軽 減することが目的であるから振幅差でよい。これによ り動き検出は大幅に簡単化される。

以上のように, 動き適応多重に伴う方式的な問題点 はなく, 送受での動き係数の整合が可能である.これ により, EDTV 受像機では順次走査信号が完全に再 生される.

\section{3 受像機ハードウェア構成}

(2)式において, $[(1-k) \cdot \mathrm{A}+k \cdot(\mathrm{B}+\mathrm{C}) / 2]$ は, 動 き適応順次走査出力であるため

$$
\begin{aligned}
\mathrm{VT} & =\mathrm{X}-[(1-k) \cdot \mathrm{A}+k \cdot(\mathrm{B}+\mathrm{C}) / 2] \\
& =\mathrm{X}-[\text { 動き適応順次走査化出力 }]
\end{aligned}
$$

と書き直せる.すなわち, 補強信号 VT は, FD信号 と LD 信号の動き適応荷重加算により作られるが, 補 間走查線 $(X)$ と動き適応補間信号の差分と等価である ことがわかる.

受像機側の復調は, (4) 式を変形して

$$
\mathrm{X}=[\text { 動き適応順次走査化出力 }]+\mathrm{VT}
$$

となる。このように, 受像機側では, 動き適応補間信 号にVT信号を加えることにより補間走查線を再生 できる. 動き係数 $k$ の求め易さはすでに述べた通り である。

受像機ハードウェア構成を図 4 に示す。VT がない 場合は, IDTV 受像機の順次走查変換回路そのもので

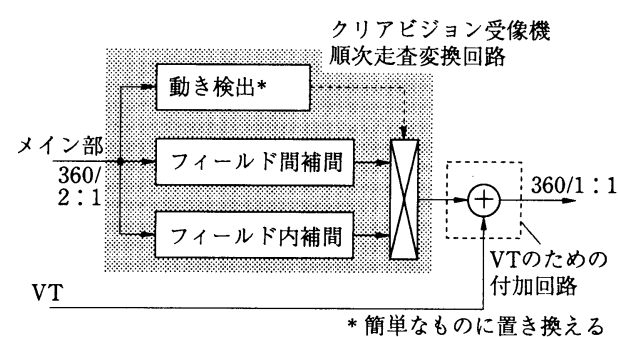

図 4 動き適応 $\mathrm{LD} / \mathrm{FD}$ 方式の受像機構成 Receiver for motion-adaptive LD/FD hybrid scheme.

ある.このため，本方式は IDTV 受像機と整合性が 良く, 簡単な回路の付加で実現できることがわかる. ただし, 動き検出はIDTV 受像機とは異なり, 全く 単純なものになる.

この結果, 下記の特長が生まれる。

（i） EDTV-IIに扔いてVTが伝送される水平低 域 (1.4 MHz 以下) と, 動き適応順次走査が行 われる水平高域 $(1.4 \mathrm{MHz}$ 以上）とで, 他の VT の場合と異なり, 処理を切替える必要がな い. 動き適応順次走查化出力に単にVTを足 せばよい。

（ii） $S / N$ 劣化などによるVT 復調停止の際にも ただ停止するだけでよい。他のVTの場合は, 動き適応処理に置換える処理を要するのに比 べ, 処理が原理的に単純である.

\section{6. ノイズに関する検討}

$\mathrm{LD} / \mathrm{FD}$ 混合方式における復調時の雑音の影響を解 析する. 雑音のないときの走查線 X(図 2 )の復調は, 前述のように下式で求められる。

$$
\mathrm{X}=\mathrm{VT}+(1-k) \cdot \mathrm{A}+k \cdot(\mathrm{B}+\mathrm{C}) / 2
$$

ここで, 雑音があるときの走査線 $\mathrm{X}$ の復元を考え る. 補強信号 VTに雑音が加わり $\mathrm{VT}^{\prime}(=\mathrm{VT}$ $+\Delta \mathrm{VT})$ となり, また, 送られている走査線 $\mathrm{A}, \mathrm{B}$, $\mathrm{C}$ に雑音が加算され, $\mathrm{A}^{\prime}(=\mathrm{A}+\Delta \mathrm{A}), \mathrm{B}^{\prime}(=\mathrm{B}+\Delta$ $\mathrm{B}), \mathrm{C}^{\prime}(=\mathrm{C}+\Delta \mathrm{C})$ になり, さらに動き係数 $k$ が $k^{\prime}(=$ $k+\Delta k)$ になるとする.

雑音を伴った走査線 $\mathrm{X}$, すなわち $\mathrm{X}^{\prime}$ は

$$
\begin{aligned}
\mathrm{X}^{\prime}= & \mathrm{VT}^{\prime}+\left(1-k^{\prime}\right) \cdot \mathrm{A}^{\prime}+k^{\prime} \cdot\left(\mathrm{B}^{\prime}+\mathrm{C}^{\prime}\right) / 2 \\
= & \mathrm{VT}+\Delta \mathrm{VT}+(1-k-\Delta k) \cdot(\mathrm{A}+\Delta \mathrm{A}) \\
& +(k+\Delta k) \cdot(\mathrm{B}+\Delta \mathrm{B}+\mathrm{C}+\Delta \mathrm{C}) / 2
\end{aligned}
$$

となる.ここで, 1 次の微小項までとると

$$
\begin{aligned}
= & \mathrm{X}+\Delta \mathrm{VT} \\
& +(1-k) \cdot \Delta \mathrm{A}+k \cdot(\Delta \mathrm{B}+\Delta \mathrm{C}) / 2
\end{aligned}
$$

固定, 適応いずれも発生する雑音 
$+\underline{\Delta k \cdot(-\mathrm{A}+(\mathrm{B}+\mathrm{C}) / 2)}$

適応処理による雑音

となる，以下，各雑音に分けて考察を行う.

（i ） $\Delta \mathrm{VT}$ ：VT 信号は受像機側で時間伸張を行 うため, $\Delta \mathrm{VT}$ が最も視覚的 $S / N$ を劣化させ る. 動き適応混合方式の場合は, VTを隇衰さ せて多重する必要がないため, 実効的に $\Delta \mathrm{VT}$ の影響を小さくできる．また，非線形圧伸，コ アリングにより雑音を低減することができる.

(ii) 固定 $(\mathrm{FD}, \mathrm{LD}$ 含む), 適応いずれも発生す る雑音： $\mathrm{FD}(k=0)$ の場合，単一項であるのに 対し, 他の場合は複数の雑音が荷重加算される ので雑音が軽減される．FDの場合を 1 とすれ ば，それぞれ下記のようになる。
LD の場合：
$\sqrt{1 / 2}=0.71$
固定混合 $(k=1 / 2)$ の場合：
$\sqrt{3 / 8}=0.61$

（iii） 適応処理による雑音の増加分：もし $\mathrm{A}$ が $\mathrm{B}$ と Cの平均值であれば,

$$
-\mathrm{A}+(\mathrm{B}+\mathrm{C}) / 2=0
$$

である.したがって、, $\Delta k$ のいかんによらず

$$
\text { (増加分) }=0
$$

である．垂直相関性を考えれば，上式の関係は ほぼ満足されるから，増加分は小さい(ただし， これが完全に満足されれば $\mathrm{LD}=0$ になる)。動 き係数 $k$ は, 送受とも広い領域で多くの画素 の平均值をとれば, $\Delta \mathrm{A}, \Delta \mathrm{B}, \Delta \mathrm{C}$ より充分小 さく, $\Delta k=0$ と見なせる. 何故なら, 他の動 き適応処理では, 動き係数 $k$ は, 原理的には 画素毎に正しい值になっていることが要求され る.一方，この場合は，送受さえ一致していれ ば多くの画素の平均とすることができるからで あり，間違っていても無画部妨害の若干の増加 となる程度である。したがって, 適応処理とす ることによる増加分は小さいといえる。

\section{7. シミュレーション実験}

動き適応 LD/FD 混合方式による無画部妨害低減効 果を確認するために, シミュレーション実験を行っ た。

画像は, 動画 2 カットと両カットのシーンチェンジ の計 3 カットについて行った．静止画については, $\mathrm{FD}$ と動き適応 $\mathrm{LD} / \mathrm{FD}$ では成分が 0 となり，LD と 固定混合より優れているのは明らかであるため，実験 を行っていない。ここに, 動画\#1（龍安寺の石庭風景 をズームアップする画像), 動画\#2（策の上にソーメ ン桶を置き，上下にパンした画像）ともに，垂直高域

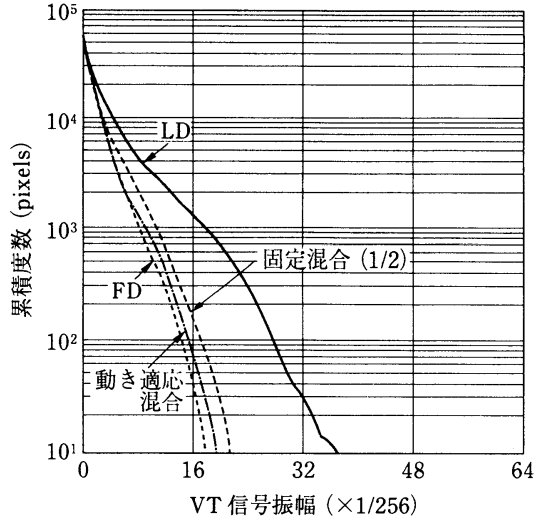

(a) 動画\# 1

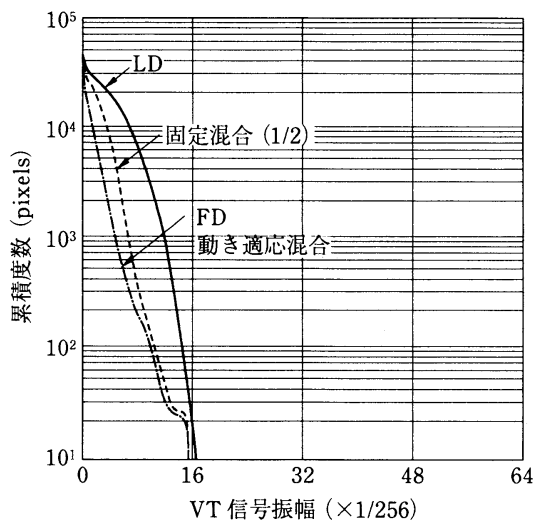

(b) 動画\# 2

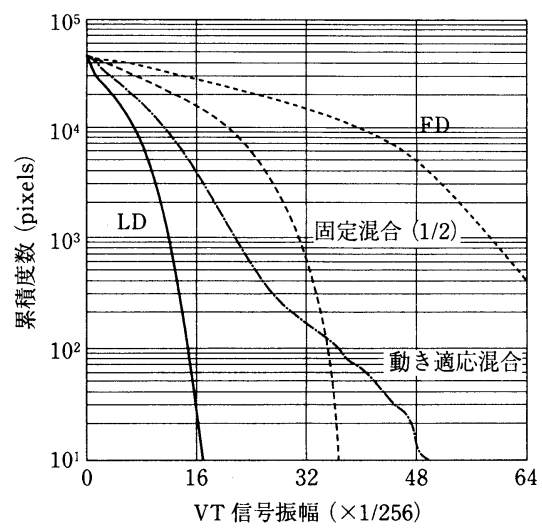

(c) シーンチェンジ (動画\#1 $\rightarrow$ \#2)

VT 振幅 : $100 \%$

全画素数 : 水平768 $\times$ 垂淔60 (無画部) $=46080$

図 5 各種 VT 信号の累積度数分布

Cumulative frequency distribution of VT signals.

成分の動きを含む画像である。ここでは，客観的に妨 害を評価するために，1 フィールド分のVT 信号の 累積度数（ある振幅以上の度数）分布を調べた．入力 信号は 8 bit 標本化し, VT 信号は入力と pp 值を合わ せるために，(2)式の值を $1 / 2$ とした值(VT 振幅：

テレビジョン学会誌 Vol. 48, No.8 (1994) 
100\%，256レベル)で測定を行った。この時, 全画素 数は, 水平 768 画素, 垂直 60 ライン(無画部)となり, 計 46080 画素となる.

シミュレーション結果を図 5 に示す. 各方式間の差 をわかりやすくするために, 縦軸を対数表示とした. デー夕曲線が上にあるほど妨害は見えやすく，累積度 数の大きいところの差ほど視覚的な影響が大きい. 動 画\#1,\#2では, LD/FD 混合方式は成分の少ない FDに漸近している。また，シーンチェンジでは, $\mathrm{FD}$ は大きい成分を持つが, $\mathrm{LD} / \mathrm{FD}$ 混合方式は成分 の少ないLDの方に近い値を示している.

以上より, 動画時には LD/FD 混合方式は FD に比 べて妨害が少ないことがわかる．静止画時には，FD と動き適応 LD/FD では妨害が全くない.よって総合 的に判断すると, 動き適応 LD/FD 混合方式が最も妨 害が少ないと考えられる。

シーンチェンジでは, 本来, 動き適応 LD/FD は LD に漸近するはずであるが，実験では漸近していな い.これは, 動きの検出漏れによると考えられる.こ れを防ぐためには, 送受でシーンチェンジを検出し て, その時には強制的に LDを選択することなどが考 えられる。

\section{8. むす び}

本論文では, VT 信号として LD/FD 混合（固定混 合, 動き適応混合）方式を提案した。特に, 動き適応 混合方式は良好な特性を示すことがわかった。

この動き適応混合方式では，原理的に信号成分が小 さいため, 無画部妨害を軽減できる.さらに, 静止領 域で本質的に歪みなく, 非線形振幅圧伸により大振幅 值を抑えることができる．同様に，コアリングにより ノイズの影響を低減できる。また，静動判定にも，従 来あった誤判定の問題は本質的に存在しない. 無画部 妨害については，シミュレーション実験により妨害軽 減効果を確認した。

また, 受像機は IDTV(例：クリアビジョン受像機) の動き適応順次走査化との整合性が良く，わずかな付 加回路で実現可能であることが明らかとなった．

本提案方式を含めた各種 VT 信号の比較表を表 2 に示した。この表からもわかるように，動き適応 $\mathrm{LD} / \mathrm{FD}$ 混合方式は, VT 信号の条件を満たす望まし い手法であると思われる。

問題点を挙げれば，処理がフィールドにまたがるこ とである．ただし，フィールド内で処理しておき，送
出の直前でこの形式にすることは可能である.

終わりに, 学会研究会や放送技術開発協議会映像作 業班（主任：木俣省英氏）で御討論を賜った各位，な らびに，日頃御指導頂く日立製作所 EDTV 推進本部 本部員 長原脩策氏に深く感謝致します.

\section{〔参 考 文 献〕}

1）柴田，谷：“現行テレビ放送と両立性のある画質政善につい ての一提案〜アイビジョン II〜”, テレビ学技報, TEBS 113-3 (Oct.1986)

2) Tsinberg: "ENTSC Two-Channel Compatible HDTV System”, IEEE Trans. Consum. Electron., CE-33, 3, pp. 146-153 (Aug. 1987)

3) M. A. Isnardi, et al.: "A Single Channel NTSC Compatible Widescreen EDTV System", 3rd HDTV Colloquim, Ottawa (Oct. 1987)

4）鈴木，石倉，影山：“EDTVにおける V-T 補強信号の理論 的考察”, テレビ学技報, BCS 92-43, pp. 31-36 (Oct. 1992)

5）芦部, 矢野：“2 次元完全再構成フィルタバンクを用いた走 查変換方式”, 1991 年テレビ年次大, 13-6(July 1991)

6）平野, 影山, 吉木：“受像機側での動き適応処理の不要な EDTV 信号の一検討”, テレビ学技報, BCS 91-5, pp. 2530 (Mar. 1991)

7) K. Kawai, S. Yasuki and N. Sakamoto: "A Wide Screen EDTV”, IEEE Trans. Consum. Electron., CE-35, 3, pp. 131 -141 (Aug. 1989)

8）守田，高橋：“レターボックス方式の評価雑音”，テレビ学 技報, BCS 92-6, pp. 25-32(Jan.1992)

9）鈴木, 影山, 吉木, 吹抜：“前置フィルタによる EDTV 無 画部妨害低減“, 1993 年テレビ年次大，13-8(July 1993)

10）鈴木, 平野, 吉木, 吹抜：“順次走査変換のための送信側擬 似動き信号の多重“, テレビ誌，42，9，pp. 966-972(Sep. 1988)

11）影山，吉木：“レターボックス EDTVにおける V-T 補強信 号の雑音低減に関する実験的検討”, テレビ学技報, BCS 93-10, pp. 7-12 (Mar. 1993)

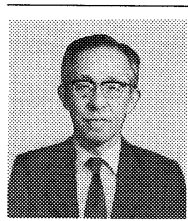

吹抜 敬彦 昭和 34 年, 京都大学工学部 電子工学科卒業. 昭和 36 年, 同修士課程修 了. 同年，(株) 日立製作所に入社. 中央研究 所に勤務. PCM 交換機の研究を経て, 画像 信号処理，特に高能率符号化や高精細テレビ 方式の研究に従事. 現在, 同所技師長. 工学 博士. 正会員.

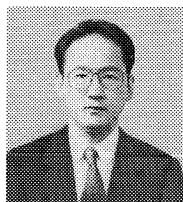

鈴袁 教洋 昭和 61 年, 東京大学大学院 修士課程修了。同年, (株) 日立製作所に入 社. 中央研究所に勤務し, 現在, 通信ネット ワーク研究セン夕研究員. 画像の信号処理に 関する研究開発に従事。正会員.

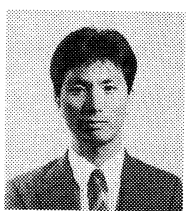

啷山゙ま 晢ひろ 昭和 62 年, 名古屋大学大学 院修士課程修了。同年, (株) 日立製作所に入 社. 中央研究所通信ネットワーク研究セン夕 研究員. 画像のディジタル信号処理に関する 研究に従事. 正会員. 